\title{
ŹRÓDŁA PISANE I ARCHEOLOGIA: PRZYKŁAD GÓRY KATEDRALNEJ W CHEŁMIE
}

\begin{abstract}
Abstrakt: Archeolodzy badający zabudowę rezydencjonalną Daniela Romanowicza na Górze Katedralnej w Chełmie (XIII w.) mają godną uwagi płaszczyznę porównań dokonywanych odkryć, z tekstem Kroniki halickowołyńskiej. Jest wysoce prawdopodobne, że przynajmniej niektóre spośród zamieszczonych w Kronice opisów miejsc i obiektów pochodzić mogą z pierwszej ręki. W artykule przedstawiono dylematy archeologa, który mając do dyspozycji różne kategorie danych, próbuje je konfrontować z zapisami kronikarskimi.
\end{abstract}

Słowa kluczowe: archeologia, księstwo halicko-wołyńskie, kronika halicko-wołyńska, Daniel Romanowicz, zespół rezydencjonalny, Góra Katedralna w Chełmie.
Abstract: Archaeologists examining the residence of Daniel Romanovych on Cathedral Hill in Chełm (thirteenth century) enjoy a noteworthy opportunity to compare excavations data with the text of Kronika halicko-wotyńska (The Galician-Volhynian Chronicle). It is highly probable that at least some of the descriptions of places and objects in the Chronicle could have been firsthand. The article discusses the dilemmas of an archaeologist who, with assorted categories of data at his disposal, tries to confront them with a chronicler's account.

Keywords: archaeology, Galich-Volyn Duchy, Galich-Volyn Chronicle, residential complex, Danylo Romanovich, Cathedral Hill in Chełm.

\section{Wstęp}

Góra Katedralna w Chełmie od ponad stu lat pozostaje przedmiotem zainteresowań archeologów, historyków-mediewistów, jak i licznych miłośników miasta ${ }^{1}$. W jej części południowej usytuowana jest bazylika pw. Narodzenia Najświętszej Marii Panny, a po stronie północnej

1 Vide A. Buko, Monumentalna zabudowa Góry Katedralnej w Chetmie, „Archaeologia Historica Polona", t. 15, 2005, nr 1, s. 69-83. 
widoczne jest charakterystyczne wyniesienie określane mianem Wysokiej Górki (ryc. 1). Cały ten obszar, w zgodnej opinii badaczy, jest rdzeniem najstarszego miasta. Na temat okoliczności i czasu zaistnienia tego ośrodka sformułowano różne hipotezy. Rosyjski archeolog Pawieł Rappoport (Pavel Aleksandrovič Rappoport), omawiając wyniki badań realizowanych na Wysokiej Górce w latach 1910-1912, podaje, że gród Danielowski został pobudowany na wcześniej już istniejącym²; podobne opinie powtarzają się w publikacjach innych autorów ${ }^{3}$. Bolesław Zimmer, powołując się na kroniki Długosza i wyniki prac archeologicznych z lat sześćdziesiątych XX w., dodaje, że gród chełmski funkcjonował wcześniej w sieci grodów czerwieńskich, a dopiero na jego gruzach Daniel Romanowicz (koronowany w roku 1253 na króla Rusi w Drohiczynie) zbudował nowy ośrodek. Tutaj przeniósł też w roku 1239 z Halicza stolicę swego księstwa ${ }^{4}$. Tymczasem w opinii Jerzego Kłoczowskiego zarówno gród chełmski, jak i towarzyszące mu podgrodzia rozwinęły się dopiero w XIII w. Dodaje, że fortyfikacje grodowe wybudowano na zalesionej górze, zatem w miejscu, gdzie zgodnie z przekazem kronikarskim nie było wcześniej osadnictwa. W świetle analiz źródeł pisanych wydzielić można, zdaniem tego autora, dwie fazy najstarszego ośrodka. W fazie pierwszej miałby to być gród na Wysokiej Górce (mały gródek), w drugiej zaś powstał gród dwuczłonowy, w którym Wysoka Górka stanowiła ostatnie refugium załogi z siedzibą księcia. W tak zaprojektowanym systemie obronnym mieścić się miała również wieża kamienno-drewniana stojąca w centralnej części Wysokiej Górki ${ }^{5}$.

Dla wyjaśnienia tych i wielu innych spornych kwestii, u progu XXI w. podjęto na Górze Katedralnej w Chelmie kolejne, tym razem interdyscyplinarne badania archeologiczne. Były to prace realizowane w ramach następujących specjalizacji: archeologia, historia, historia architektury, geologia, geomorfologia, archeometria, archeozoologia, archeobotanika i wiele innych. Prace te, trwające po dzień dzisiejszy, ujawniły wiele nowych, nieznanych dotąd odkryćc. Te nowo pozyskane zasoby źródłowe

2 P.A. Rappoport, Cholm, „Sovetskaâ arheologiâ” 1954, t. 20, s. 313-323.

3 Vide A. Poppe, Gród Wotyń. Z zagadnień osadnictwa wczesnośredniowiecznego na pograniczu polsko-ruskim, „Studia Wczesnośredniowieczne”, t. 4, 1958, s. 250.

${ }^{4}$ B. Zimmer, Miasto Chełm. Zarys historyczny, Warszawa-Kraków 1974, s. 15.

${ }^{5}$ J. Kłoczowski, Zarys historii rozwoju przestrzennego miasta Chełma, RHum, t. 6, 1958, z. 5, s. 195 n.

${ }^{6}$ Vide A. Buko i in., A palatium or residential complex? Recent research into the northern part of Góra Katedralna (Wysoka Górka) in Chełm / Palatium czy zespót rezydencjonalny? Pótnocna część Góry Katedralnej w Chetmie (Wysoka Górka) w świetle wyników najnowszych badań, „Sprawozdania Archeologiczne”, t. 66, 2014, s. 101-154. 
stwarzają znakomitą okazję konfrontacji najnowszych odkryć z zapisami kronikarskimi. W przypadku Chełma dogodną podstawę źródłową narracji o mieście doby danielowskiej stanowi przekaz Kroniki halicko-wołyń$\mathrm{skiej}^{7}$. Jej autor, w niektórych kwestiach nader dobrze obeznany z realiami chełmskimi, nie stroni od wielu szczegółów odnoszących się zarówno do topografii miasta danielowskiego, jak i elementów jego zabudowy. Stąd wydaje się wysoce prawdopodobne, że przynajmniej niektóre spośród zamieszczonych w Kronice opisów miejsc i obiektów pochodzić mogą z pierwszej ręki. Mam na myśli zwłaszcza akapit dotyczący opisu świątyni (kaplicy pałacowej?) pw. św. Jana Chryzostoma. Jest tam zbyt wiele szczegółów, dotyczących formy, stylistyki i detali wystroju architektonicznego kościoła, nad którymi zatrzymuje się autor kroniki. Z kolei niejasność innych akapitów, konfrontowanych z danymi archeologii, wskazywać może, że w tych przypadkach mamy do czynienia z niejednoznacznością terminologiczną (np. dalej cytowany przykład bieławińskiego stołpu), niejasnościami przekazów bądź też z brakiem kontekstów, dla których dany obiekt należało opisać dokładniej (por. dalej przykład pozostałych świątyń chełmskich czy formy i topografii rezydencji książęcej). Stąd zgodzić należy się z opiniami autorów wskazujących na zróżnicowany co do szczegółowości charakter zapisów kronikarskich i związane z tym faktem implikacje ${ }^{8}$.

Dla archeologa, nie będącego specjalistą w zakresie krytycznej analizy tekstów źródłowych, konfrontacja zapisów kronikarskich z odkryciami archeologicznymi jest trudnym wyzwaniem. Przekazy kronikarskie w ograniczonym tylko stopniu odnoszą się bowiem do zjawisk, rzeczy i wydarzeń, obserwowalnych poprzez źródła archeologiczne. W niniejszym artykule przedstawiono zatem głównie dylematy archeologa, który ma do dyspozycji różne kategorie danych i próbuje konfrontować je z zapisami kronikarskimi. Ujawniają one blaski i cienie wnioskowania, ale zarazem generują pytania, bez których nasza wiedza o przeszłości byłaby zdecydowanie bardziej ułomna.

7 Ipat'evskaâ letopis', w: Polnoe sobranie russkih letopisej, t. 2, Moskva 2001 [reprint wydania S.-Peterburg 1908]; cytowany niżej ustęp kroniki w tłumaczeniu Dariusza Dąbrowskiego (vide D. Dąbrowski, „Źródła pisane do dziejów Góry Katedralnej w Chełmie”, w: „Zespół rezydencjonalno-sakralny na Górze Katedralnej w Chełmie”, red. A. Buko, Warszawa 2013, mps w Archiwum Instytutu Archeologii i Etnologii (dalej: IAE) PAN w Warszawie.

8 Szerzej na ten temat pisali ostatnio A. Jusupović, „Богу же изволившю Даниль созда градъ Холмъ”. Geneza Chełma i jego biskupstwa, „Rocznik Instytutu Europy Środkowo-Wschodniej" 12, 2014, z. 6, s. 11-26 oraz D. Dąbrowski, op. cit.; w cytowanych pracach starsza literatura. 


\section{Elementy danielowskiego Chełma w przekazie Kroniki halicko-wołyńskiej}

W kontekście opisywanego w kronice Chełma odpowiedni zapis kroniki jest następujący:

Chełm gród tak był stworzony z polecenia bożego. Daniel [,] panując we Włodzimierzu [,] założył gród Uhrusk i postawił w nim biskupa. Gdy jeździł po polu [,] czyniąc łowy, zobaczył miejsce piękne i zalesione na górze. obchodząc je dookoła polem [wersja alternatywna: otoczone dookoła polem], zapytał tuziemców: „Jak się nazywa to miejsce?”. Oni powiedzieli: "Jego nazwa jest Chełm”. I polubił to miejsce i pomyślał, aby założyć na nim gródek mały, obiecując Bogu i św. Janowi Złotoustemu, że zbuduje [tam] cerkiew pod jego wezwaniem [w jego imię]. i zbudowa[ł] gródek mały i widział, że Bóg pomocnikiem jego i święty Jan wspomożycielem [,] i stworzył gród inny. Jegoż Tatarzy zdobyć nie zdołali, kiedy Batu wziął całą ruską ziemię. Wtedy i cerkiew świętej Trójcy spalona była i na powrót zbudowana była. Widział to książę Daniel, że Bóg pomaga miejscu temu, zaczął przyzywać, przychodźców - Niemcy i Ruś, innoplemieńcy i Lachowie szli dzień w dzień i młodzi [,] i majstrowie wszelacy uciekali od Tatarów, siodlarze i łucznicy [,] i tulnicy [wytwórcy kołczanów] [,] i kowale żelaza i miedzi [,] i srebra, i było życie i napełnili dwory wokół grodu, pole i sioła. Zbudował cerkiew świętego Jana piękną i doskonałą. Struktura jej taka była. Arkady 4 [,] z każdego rogu sklepienie [,] a podstawa ich na 4 głowach ludzkich, stworzonych przez niejakiego rzemieślnika/mistrza. Okna 3, upiększone szkłem rzymskim [witrażami]. Wchodząc do ołtarza [,] stoją dwie kolumny, całe kamienne [,] i na nich arkada/sklepienie i wyżej kopuła ozdobiona złotymi gwiazdami na lazurze. Wewnętrzna jej [,jej” przypuszczalnie dotyczy cerkwi, analogia w następnym zdaniu] posadzka była odlana z miedzi i ołowiu czystego tak błyszczącego, jak zwierciadło. Drzwi jej dwoje ozdobionych kamieniem halickim białym i zielonym chełmskim ciosanym [chodzi bez wątpienia o portale, a nie drzwi jako takie]. Wyrzeźbione przez niejakiego mistrza Awdieja [z] ozdobami [we] wszystkich barwach i złocie. Z przodu ich [tzn. w zachodnim portalu] zrobiony był Zbawiciel, a na północnych święty Jan, który budził zadziwienie patrzących. Ozdobi [Daniel] ikony, które przyniesie z Kijowa [,] kamieniem drogim i bisiorem i złotem. Wyobrażenie Zbawiciela i przeczystej Bogurodzicy, które dała jemu siostra Fiodora z monastyru Fiodora. Ikonę przyniósł [też] z Owrucza od ojca jego Ofiarowania Pańskiego dziwowi podobne. Zgorzały one w cerkwi świętego Jana, jeden Michał ostał się. Cudne te ikony i dzwony przyniesie z Kijowa. Inne tu odleje, to wszystko ogień popali. Wieża pośród grodu wysoka, z której ostrzeliwać [można było] dookoła/wokół grodu, podbudowana kamieniem na wysokość 15 łokci, zbudowana sama z drewna ciosanego i pobielona jak ser [twaróg], świeciła się na wszystkie strony. Studzieniec zwany inaczej 
kladjaz [studnia] blisko jej był, sążni mający 35. Świątynie przepiękne [pewnie - były,] miedź od ognia [stopiona] jako smoła pełzła. Posadzi sad piękny i zbuduje cerkiew na cześć świętych altruistów [Kuźmy i Damiana] miała [ona] 4 kolumny całe z kamienia, wyciosane, podtrzymujące kopułę, z tegoż [materiału] inne, i ołtarz przeświętego Dymitra. Stoi cis/cedr/sosna przed bocznymi drzwiami piękny [,] przyniesiony z daleka. Stoi stołp popriszcze [w zależności od stosowanej miary około 1,14-1,47 km] od grodu kamienny, a na nim orzeł kamienny rzeźbiony, wysokość kamienia dziesięć łokci z głowami/głowicą i z podnóźkami/podstawą, 12 łokci. Zobaczywszy taki przepadek grodu, wszedł do cerkwi i widząc zniszczenie [jej,] rozżalił się wielce [,] pomodlił się do Boga [,] potem odnowi[ł] i cerkiew [,] którą poświęci[ł] biskup Iwan. I potem pomodli się do Boga, i zbuduje mocniejsze i wyższe [cerkwie]. Wieży takiej, nie może stworzyć, bowiem grody inne budował był przeciw bezbożnym Tatarom, przez to nie uczynił jej. Zbuduje cerkiew przewielką, w grodzie Chełmie, w imię Przeświętej Dziewicy Maryi [,] pod względem wielkości i piękna nie mniej będącej niż wcześniejsze. I ozdobi ją przecudnymi ikonami. Przyniesie czaszę z ziemi węgierskiej, z marmuru purpurowego/porfiru wyrzeźbioną mądrością cudną i smocze głowy były wokół niej [,] i postawi ją przed drzwiami cerkiewnymi, zwanymi carskimi. Zbuduje w niej chrzcielnicę, by chrzcić wodę na święte Objawienie zbuduje w niej błogosławiony biskup Iwan, z drewna pięknego, toczony i pozłacany, w środku, i na zewnątrz zadziwieniu podobny [podejrzewam, że zdanie jest oberwane i zabrakło określenia, czym jest, to coś toczone i złocone] $]^{9}$.

9 "[6767 r.] Cholm bo gorod siče byst' sozdan Božim velen'em Danilovi bo knjažašču vo Volodimjerje sozda grad Ugoresk' i postavi vo nem' piskupa jazdiašču že emu po polju i lovy djejušču i vidje mjesto krasno i ljesno na gorje obchodjašču okrug ego polju i vopraša tozemjec' kako imenuetsja mjesto se oni že rekoša Cholm emu imja est' i vozljubiv mjesto to i pomysli da sožižet na nem gradec mal obješčasja Bogu i svjatomu Ivanu Zlatoustu da stvorit' vo imja ego cerkov i stvori gradjec mal i vidjev že jako Bog pomoščnik emu i Ioan' spješnik emu est' i sozda grad inyi egože Tatarove ne vozmogoše prijati egda Batyi vsju zemlju Ruskuju poima togda i cerkov svjatoi Troicje zažžena byst' i paki sozdana byst' vidiv že knjaz' Danilo jako Bog pospjevajušču mjestu tomu nača prizyvati prichodaje Njemcje i Rus' inojazyčniki i Ljachy idjachu den' i vo den' i unoty i masterje vsjacii bježachu is Tatar sjedjelnici i lučnici i tulnici i kuznicje željezu i mjedi i srebru i bje žizn' i napolniša dvory okrest krada pole sela sozda že cerkov svjatogo Ivana krasnu i ljepu zdanje že eja siče byst' komary s každo ugla prevod i stojan'e ich na četyrech golovach čelovecskich izvajano ot njekoego chytrječ' okna 3 ukrašena stekly Rim'skimi vchodjašči vo oltar' stojasta dva stolpa ot cjela kameni i na neju komara i vyspr' že vjerch Ukrain zvjezdami zlanymi na lazurje vnutr'nyii že ei pomost bje slit ot mjedi i ot olova čista jako bleščatisja jako zerčalu dvjeri že ei dvoja ukrašeny kamen'em Galičkym bjelym i zelenym Cholmskym tesanym uzory tje nekim chytrječem' Avd'em' priljepy ot vsjech šarov i zlata napredi ich že bje izdjelan Cspas a na polunoščnych svjaty Ivan jakože vsim zrjaščim divitisja bje ukrasi že ikony eže prinese is Kyeva kamen'em dragym i biserom zlatym i Spasa prečistoe Bogorodicje iže emu sistra Fedora i vda iż monastyrja Fedora ikony že prane izo Uručego Ustrjeten'e ot otcja ego divu 
Jak dane te odnieść do odkryć archeologicznych dotyczących Chełma z połowy wieku XIII? Jest to zasadnicze pytanie, na które w niniejszym artykule szukamy odpowiedzi.

\author{
Chełm czasów Daniela w świetle analizy \\ porównawczej danych archeologicznych \\ i źródeł pisanych
}

\title{
Położenie ośrodka
}

W cytowanym wyżej tekście kroniki znalazł się na ten temat następujący akapit: „Gdy jeździł [Daniel - przyp. A.B.] po polu [,] czyniąc łowy, zobaczył miejsce piękne i zalesione na górze. Obchodząc je dookoła polem [wersja alternatywna: otoczone dookoła polem], zapytał tuziemców: «Jak się nazywa to miejsce?». Oni powiedzieli: «Jego nazwa jest Chełm»".

Ten fragment tekstu zawiera kilka elementów charakterystycznych. Wynika z niego, że wokół dzisiejszego miasta było pole uprawne (?), choć centralnym elementem krajobrazowym była tu najpewniej zalesiona góra. Jej widok musiał być szczególny, skoro zwróciła uwagę księcia. Zgodnie z przekazem kroniki zamierzał on w tym miejscu wybudować gród i świątynię. Również dzisiaj Góra Katedralna w Chełmie pozostaje charakterystycznym elementem miejskiego krajobrazu (por. ryc. 1).

podobny jaže pogorješa vo cerkvi svjatogo Ivana odin Michail ostasja čjudnych tjech ikon i kolokoly prine is Kyeva drugyja tu sol'e to vse ogn' popali veža že sredje goroda vysoka jakože biti s neja okrest grada podszdana kameneem v' vysotu 15 lakot sozdana že sama devom tesanym i ubjelena jako syr svjataščisja na vsei storony stjudenjec' rekomyi kladjaz' bliz eja bje saženii imušči 35 chramje prekrasnii i med. ot ognja jako smola polzušč posadi že sad krasen i sozda cerkov svjatyma bezmjezdnikoma vo čest' imat' 4 stolpy ot cjela kameni istesanago deržaša vjerch s tjech že drugi i voltar' presvjatogo Dmitreja stoit' že ti pred bočnymi dvjermi krasen prinesen izdaleča stoit' že stolp popia ot Gorola kamen a na njem' orel kamen izvajan vysota že kameni desjati lakot s govonami že i s podnožkkami 12 lakot uvidiv že sicju pagubu gradu všed vo cerkov' i vide pagubu i sžalisi veli pomolivsja Bogu paki obnosi i cerkov' osvjeti piskupom Ivanom i paki pomolivsja Bogu i sozda tv'rž’ i vyša vežje že takoe ne vozmože sozdati bje bo grady inyja žižai protivu bezbożnym Tatarom za to ne sozda eja.

V ljeto 6768. Sozda že cerkov priveliku vo gradje Cholmje vo imja presvjatyja prisnodevicja Marija veličestvom krasotoju ne mene suščich drevnich i ukrasi ju prečjudnami ikonami prinese že čašju ot zemlja Ugor'skyja mramora bagrjana izvajanu mudrost'ju čjudnu i zm'evy glavy bješa okrug eja i postavi ju pre dvjermi cerkovnymi narjecaemymi carskimi stvori že v nei krestilnicju krestiti vodu na svjatoe Bogojavlenie stvori že v nei blaženyi piskup Ivan ot dreva krasna točen i pozlaščen dnje i vnje divlaniju podoben" (transkrypcja tekstu Kroniki halicko-wołyńskiej wg D. Dąbrowskiego, por. przyp. 7). 
To wokół niej rozwinęło się współczesne miasto. Gdzie jednak zamieszkiwali mieszkańcy, których spotkał wracający z łowów Daniel - trudno na podstawie krótkiej wzmianki kronikarskiej zidentyfikować. Co najwyżej można się domyślać, że miejsce to było już zasiedlone (książę spotkał bowiem tuziemców) i miało swą nazwę (Chełm). Nierozstrzygniętą kwestią pozostaje, czy nazwa ta odnosiła się tylko do Góry jako takiej, czy też ogólniej - do ośrodka wczesnomiejskiego (polskiego? ruskiego?), który funkcjonował tu wcześniej i z nieznanych względów popadł w ruinę lub wręcz przestał istnieć. Nie wiemy też, czy napotkani wówczas ludzie byli rolnikami i czy zamieszkiwali na terenie dawniejszego ośrodka grodowego.

Archeologia nie dostarcza wielu przykładów wczesnego zasiedlenia terenów obecnego miasta. Poza pojedynczymi fragmentami naczyń, pochodzących z terenu Góry Katedralnej, które odnieść można do okresu XI w., nie odsłonięto dotąd bowiem obiektów, których czas powstania i użytkowania można by przypisać do okresu wczesnopaństwowego ${ }^{10}$. Do wyjątków należą świadectwa starszego osadnictwa z Chełma-Bieławina ${ }^{11}$. W bezpośrednim otoczeniu Góry Katedralnej, z XII wiekiem (?) łączą się odkrycia grobów szkieletowych, zidentyfikowanych podczas badań archeologicznych w latach ubiegłych, przy ul. Krzywej. Oznacza to, że przed powstaniem Chełma danielowskiego, było w tym rejonie skupisko osadnicze ${ }^{12}$. Jego charakter, a tym bardziej cechy szczególne pozostają jednak zagadką.

W kontekście poruszanych zagadnień nie można wykluczyć, że podobnie jak w innych przypadkach, omawiane wyniesienie pośrodku dzisiejszego miasta pełnić mogło w okresie wczesnego średniowiecza funkcje symboliczne. Na rzecz tego kierunku interpretacji przemawiać mogą odkrycia w innych częściach kraju miejsc o podobnej lub identycznej nazwie, łączonych z określonymi funkcjami religijnymi w okresie przedpaństwowym ${ }^{13}$. Na temat kultowej funkcji Góry Katedralnej w Chełmie

10 Vide T. Dzieńkowski, Das mittelalterliche Chetm im Lichte archaologischer Quellen / Średniowieczny ośrodek chełmski w świetle źródeł archeologicznych, „Analecta Archaeologica Ressoviensia", t. 7: Archaeology in a town, a town in archaeology, 2012, s. 371-458.

11 Vide U. Ruszkowska, Ze studiów nad wczesnośredniowiecznym rejonem osadniczym w Chetmie-Bieławinie, „Lubelskie Materiały Archeologiczne”, t. 3, 1990, s. 55-89; eadem, Chełm-Bieławin. U źródeł miasta, w: Badania archeologiczne o poczatkach i historii Chełma, red. E. Banasiewicz-Szykuła, Lublin 2002, s. 37-56.

12 Vide T. Dzieńkowski, Góra Chetmska we wczesnym średniowieczu, w: Badania archeologiczne o początkach $i$ historii Chełma, s. 73-83; idem, „Wczesnośredniowieczne osadnictwo ziemi chełmskiej", Chełm 2010, mps pracy doktorskiej w Archiwum IAE PAN w Warszawie; w cytowanych pracach dalsza literatura.

${ }^{13}$ Vide A. Buko, Archeologia Polski wczesnośredniowiecznej. Odkrycia-hipotezy-interpretacje, wyd. 3, Warszawa 2011, 116 n.; tam dalsze przykłady i literatura. 
wypowiadano się w literaturze przedmiotu wielokrotnie ${ }^{14}$. I choć archeologia nie dostarcza w tej sprawie rozstrzygających argumentów, wątek ów przewija się nadal w pracach archeologów ${ }^{15}$.

\section{Gród na Górze Katedralnej w Chełmie}

Drugą, podnoszoną wielokrotnie w literaturze przedmiotu kwestią jest lokalizacja i chronologia grodu chełmskiego, rozumianego jako regionalny ośrodek władzy. W tekście Kroniki znajdujemy na ten temat niewiele: „I polubił to miejsce i pomyślał, aby założyć na nim gródek mały, obiecując Bogu i św. Janowi Złotoustemu, że zbuduje [tam] cerkiew pod jego wezwaniem. i zbudowa[ł] gródek mały i widział, że Bóg pomocnikiem jego i święty Jan wspomożycielem [,] i stworzył gród inny. Jegoż Tatarzy zdobyć nie zdołali, kiedy Batu wziął całą ruską ziemię".

Z przytoczonego fragmentu tekstu wynika, że inwestycje Danielowskie na Górze Katedralnej objęły dwa etapy budowy: najpierw wybudowano starszy gród z kościołem św. Jana Złotoustego, następnie gród większy. Ten ostatni musiał być dobrze umocniony, skoro jak podaje kronikarz, Tatarzy nie zdołali go zdobyćc ${ }^{16}$.

Konfrontacja tych lakonicznych danych z realiami archeologicznymi nie pozwala na jednoznaczną ich identyfikację. Co więcej, w świetle wyników ostatnich badań pod nazwą grodu kryją się nie tyle umocnienia drewniano-ziemne, ile raczej kamienna fortalicja, której elementy zidentyfikowano podczas badań w południowej części Wysokiej Górki. Mam na myśli wykonany z prostokątnych ciosów kamiennych mur obwodowy, odsłonięty w trakcie badań archeologicznych, oraz dwie kamienne budowle zidentyfikowane w jego obrębie (ryc. 2); te ostatnie zachowały się jedynie w partiach fundamentowych. Jedna $\mathrm{z}$ nich przypomina forma kościół z prostokątnym prezbiterium, podczas gdy druga, o formie prostokąta, mogła być wieżą rezydencjonalną (?) (por. ryc. 2). Na temat pozostałych (świeckich) budowli fazy I, ich elementów konstrukcyjnych i formy grodu, a tym bardziej szczegółów jego umocnień, w Kronice halicko-wołyńskiej nie ma danych. Jedynie kościół grodowy wywarł na autorze Kroniki wrażenie szczególne. Tezę tę dokumentuje nadzwyczaj

14 P.A. Rappoport, op. cit.; K. Natkański, Początki kultu na Górce Chełmskiej, „Eastern Review", t. 4, 2000, s. 411-423.

${ }^{15}$ Vide U. Ruszkowska, Czy na Górce Chełmskiej znajdowało się miejsce kultu pogańskiego?, „Eastern Review”, t. 4, 2000, s. 405-410.

16 O. Baran, Datuvannâ zasnuvannâ mista Holma v Galic'ko-Volins'komu litopisì, „Ukraïna v Central'no-Shìdnìj Êvropì (z najdavnìših časìv do kìncâ XVIII st.)”, nr 5, 2005, s. 428-448; idem, Rann'omoderna knižna tradiciâ pro Holm XI stolittâ, „Ruthenica”, t. 4, 2005 s. $98-114$. 
skrupulatny opis zarówno formy świątyni, jak i jej detali i wyposażenia (por. wyżej tekst kroniki). Byłoby to niemożliwe, gdyby autor kroniki tych wspaniałości naocznie nie oglądał. Tymczasem identyfikacja archeologiczna szczegółów konstrukcyjnych świątyni, w tym dwóch monumentalnych portali, a tym bardziej ich relacje do istniejących w tej części wzgórza budowli świeckich, jest zadaniem trudnym do przeprowadzenia. Na przeszkodzie stoi tu szczątkowy stan zachowania odkryć. Można się jedynie domyślać, że zarówno część sakralna, jak i świecka zabudowy wzgórza zorientowane były na tej samej osi (por. ryc. 2). Przypuszczalnie część odsłoniętych w trakcie badań detali architektonicznych pochodziła z wystroju kościoła.

Niezależnie od tych i wielu innych wątpliwości, na obecnym etapie badań podstawą do dalszych dyskusji pozostaje teza sformułowana przez Teresę Rodzińską-Chorąży ${ }^{17}$, że w spągu fundamentów prostokątnej budowli kamiennej i przylegającej do niej od strony wschodniej innej budowli (obiekt sakralny?) tkwią pozostałości pierwotnego założenia zapewne wieży mieszkalno-obronnej oraz grodowej cerkwi św. Jana Złotoustego. Na obraz pierwotnej rezydencji składałyby się zatem mury obwodowe z bramą oraz na dziedzińcu - zapewne dwie budowle, z których jedna być może była wieżą mieszkalno-obronną, druga zaś - o planie zarysowującym prostokąt - była budowlą sakralną. Obie mogły być umieszczone pośrodku dziedzińca na jednej osi. Autorka ta uznaje zarazem, że budowla sakralna składała się z dwóch części: nawy oraz prezbiterium. Zapis Kroniki halicko-wołyńskiej mówiący, że: „z każdego rogu sklepienie, a podstawa ich na głowach ludzkich", wskazuje, iż mogła ona być przesklepiona sklepieniem krzyżowym lub krzyżowo-żebrowym. W literaturze przedmiotu już wcześniej odnotowano, że opis zawarty w Kronice, dotyczący co prawda świątyni pw. św. Jana Złotoustego, wskazuje na łączenie w jednej bryle cech charakterystycznych dla Kościoła wschodniego oraz zachodniego (rzymskiego) ${ }^{18}$.

W poszukiwaniu analogii do omawianej budowli zwraca się uwagę, że najbardziej odpowiadająca planem i chronologią obiektowi chełmskiemu wydaje się najstarsza faza kościółka w Spasie-Podgórzu, badanego w latach ubiegłych, datowana na drugą połowę XIII w. (ryc. 3) ${ }^{19}$.

17 T. Rodzińska-Chorąży, „Relikty architektoniczne zespołu rezydencjonalnego na Wysokiej Górce w Chełmie”, w: „Zespół rezydencjonalno-sakralny na Górze Katedralnej w Chełmie".

18 Vide M. Smorąg-Różycka, L'Architecture sacrale orthodoxe de Galicie-Volhynie du XIIIe siècle: une synthèse des formes traditionnelles Byzantines et romanes?, „Byzantina et Slavica Cracoviensis", t. 3, 2001, s. 181-192.

19 Vide S. Rudnik, Wyniki badań architektonicznych kościoła w Podgórzu, gm. Chełm, 
Zdaniem autora niniejszego artykułu opisywaną fazę zabudowy Góry Katedralnej odnieść można do czasu pomiędzy 1236 r. a pierwszą połową lat czterdziestych XIII w., kiedy to Daniel pojawił się w Chełmie i wówczas najpewniej podjął duże inwestycje budowlane ${ }^{20}$.

Niejasna pozostaje topografia grodu Danielowskiego fazy młodszej, tj. po pożarze z 1256 r. Z badań archeologicznych wynika, że kolejna faza rozbudowy objęła co najmniej centralną część wzgórza. Wówczas to w koronie muru obwodowego północnego pojawia się prostokątna wieża kamienna o długości ścian nieco powyżej $11 \mathrm{~m}$. Jej centralne położenie i strategiczne znaczenie wyraźnie akcentuje tekst kroniki: „Wieża pośród grodu wysoka, z której ostrzeliwać [można było] dookoła/wokół grodu, podbudowana kamieniem na wysokość 15 łokci, zbudowana sama z drewna ciosanego i pobielona jak ser [twaróg], świeciła się na wszystkie strony". W jej pobliżu, zgodnie z zapisem kronikarskim, winna znajdować się głęboka studnia („Studzieniec tak zwana studnia blisko jej był, sążni mający 35”).

W trakcie badań archeologicznych odsłonięto dolną część budowli wieżowej, zatem trudno wypowiadać się na temat szczegółów konstrukcyjnych jej wyższych kondygnacji (ryc. 4). Ale centralne jej położenie i obecność kolejnych obiektów monumentalnych po północnej części Wysokiej Górki ${ }^{21}$ wskazują bezdyskusyjnie na jej czołową pozycję strategiczną w obwodzie zespołu rezydencjonalnego. Bardziej skomplikowana wydaje się natomiast kwestia lokalizacji wymienionej w kronice studni, jaka miała się znajdować blisko wieży. W trakcie badań na obiekt tak usytuowany nie natrafiono. Co prawda studnia, podobna (głębokością) do opisywanej, została zidentyfikowana, ale już poza obrębem zespołu rezydencjonalnego, w ogrodach na terenie obecnej parafii ${ }^{22}$. W sprzeczności z zapisem kronikarskim stoi więc jej zbyt odległe położenie. Nie można jednak wykluczyć, że na omawianym terenie znajduje się jeszcze jedna, nie ujawniona dotąd w wyniku badań studnia. Jeżeli tak było, to jej lokalizacji doszukiwać się należałoby po północnej, nie badanej dotąd części wzgórza.

w: Najważniejsze odkrycia archeologiczno-architektoniczne Chełma i okolic. Materiały z sesji naukowej odbytej w Chetmie 1 XII 1995 r., red. S. Gołub, Chełm 1997, s. 39-52.

${ }^{20}$ Wcześniejszą chronologię tych wydarzeń przyjmuje na podstawie analizy źródeł pisanych D. Dąbrowski, op. cit.; por. też na ten temat T. Rodzińska-Chorąży, op. cit.

${ }^{21}$ Nie publikowane badania wykopaliskowe Tomasza Dzieńkowskiego (materiały i dokumentacja z badań zdeponowane w Wojewódzkim Urzędzie Ochrony Zabytków w Lublinie Delegatura w Chełmie).

${ }^{22}$ K. Natkański, Studnia na Górce Katedralnej w Chełmie, „Rocznik Chełmski”, t. 3, 1997, s. 383-391; S. Gołub, Badania archeologiczne chełmskich studni zabytkowych, ,Rocznik Chełmski”, t. 3, 1997, s. 369-381. 


\section{Wielki pożar miasta w 1256 r.}

Jednym z centralnych wątków poruszanych przez autora kroniki jest pożar zespołu grodowego, jaki miał miejsce w roku $1256^{23}$. W Kronice znaleźć można na ten temat kilka wzmianek. Pierwsza z nich pojawia się w kontekście niezidentyfikowanej dotąd cerkwi św. Trójcy: „Wtedy i cerkiew świętej Trójcy spalona była i na powrót zbudowana była". Niestety, nie bardzo wiadomo, gdzie się świątynia ta znajdowała, a tym bardziej, jaka była jej forma. Nie można wykluczyć, że jej pozostałościami są odkryte ostatnio w północnej części Wysokiej Górki relikty monumentalnej kamienno-ceglanej budowli, ze śladami silnego pożaru. Obiekt ten - zidentyfikowany w roku 2013 - odsłonięty został dotąd fragmentarycznie, co uniemożliwia określenie jego funkcji i formy ${ }^{24}$.

Do kwestii wielkiego pożaru nawiązuje też tekst Kroniki przy okazji omawiania tragicznych losów świętych ikon i spustoszenia przez żywioł samego grodu: „Ikonę przyniósł [też] z Owrucza od ojca jego Ofiarowania Pańskiego dziwowi podobne. Zgorzały one w cerkwi świętego Jana, jeden Michał ostał się. [--] Inne [dzwony] tu odleje, to wszystko ogień popali[ł]. [--] Świątynie przepiękne [były,] miedź od ognia [stopiona] jako smoła pełzła. [--] Zobaczywszy taki przepadek grodu, wszedł do cerkwi i widząc zniszczenie [jej,] rozżalił się wielce".

Świadectwa wielkiego pożaru z roku 1256 były wszechobecne w trakcie badań archeologicznych. Są to zarówno intensywne warstwy pożarowe, demolicje zniszczonych struktur (ryc. 5), jak i liczne znaleziska stopionego ołowiu (?) - być może pozostałości opisywanej w kronice wspaniałej posadzki z kościoła św. Jana.

Daniel, poruszony skalą zniszczeń, zdecydował podjąć dzieło odbudowy, co znajduje odbicie w kolejnym ustępie kroniki: „I potem pomodli się do Boga, i zbuduje mocniejsze i wyższe [cerkwie]". Świadectwem tych działań są odsłonięte w trakcie badań archeologicznych mury dostawione do kamiennych partii fundamentowych jednej z tych budowli (cerkiew św. Jana?), co interpretować należy jako wzmocnienie fundamentów, a zarazem powiększenie istniejących w tym miejscu struktur (ryc. 6).

Odkrycia archeologiczne korespondują zatem z przekazami Kroniki halicko-wołyńskiej odnotowującej, że po pożarze z końca 1256 r. cerkiew została wzmocniona i podwyższona. Niestety, szczegółów tej przebudowy nie jesteśmy w stanie przybliżyć. Zdaniem Dariusza Dąbrowskiego, analizującego ten fragment tekstu kroniki, obiekt nie został zniszczony doszczętnie w wyniku pożaru. Jego przekształcenia nie miały więc

\footnotetext{
${ }^{23}$ Por. D. Dąbrowski, op. cit.

24 Por. przyp. 11.
} 
charakteru gruntownej rekonstrukcji, lecz raczej rozbudowy, w oparciu o zachowaną nadal substancję architektonicznąa ${ }^{25}$.

Z tekstu kroniki wynika też, że również centralnie zlokalizowanej wieży książę nie odbudował: „Wieży takiej, nie może stworzyć, bowiem grody inne budował był przeciw bezbożnym Tatarom, przez to nie uczynił jej”. Czyżby koszt jej odbudowy był tak wielki, że porównywany mógł być tylko z nowymi inwestycjami grodowymi? W trakcie prac archeologicznych we wnętrzu wieży wydzielono sześć poziomów użytkowych w postaci warstewek i przekładek (w tym ślady drewnianych podłóg) oraz posadzki z kamienia. We wszystkich warstwach wystąpiła duża liczba odpadów pokonsumpcyjnych. Najmłodsza warstwa wydatowana została groszem praskim na drugą połowę XIV w. Wszystko to wskazuje, że wieża w jakiejś formie funkcjonowała jeszcze w okresie po śmierci Daniela ${ }^{26}$.

W Kronice halicko-wołyńskiej przewija się też wątek poprzedniczki obecnej bazyliki katedralnej Narodzenia NMP: „Zbuduje cerkiew przewielką, w grodzie Chełmie, w imię Przeświętej Dziewicy Maryi [,] pod względem wielkości i piękna nie mniej będącej niż wcześniejsze”.

Świątynia ta została zidentyfikowana w trakcie naszych badań realizowanych wewnątrz bazyliki chełmskiej w latach 2013-2015. Była to budowla jednonawowa z prostokątnym (lub półokrągłym) prezbiterium; kwestie te ze względu na trudności techniczne prac wykopaliskowych wewnątrz bazyliki katedralnej nie znalazły dotąd jednoznacznego rozstrzygnięcia. Zaskoczeniem było stwierdzenie, że świątynia została wybudowana z romańskiej cegły, co uznać można za ewenement w budownictwie Kościoła wschodniego (ryc. 7). W opinii specjalistów, najstarsza bazylika była dziełem warsztatu zachodniego (Kościoła rzymskiego), co stanowi o jej niezwykłości na tle miejsca i epoki. Odnotujmy też, że w zapisie kronikarskim kamień i cegła są zapewne synonimami budowli... kamiennych, ponieważ kronikarz nie dokonuje w tym zakresie podstawowych rozróżnień. Nie znalazła natomiast potwierdzenia opinia kronikarza o znaczącej wielkości tej świątyni. Jej wymiary $15 \times$ 22-25 (?) m w stosunku np. do kamiennego soboru Zaśnięcia Przenajświętszej Bogurodzicy w Kryłosie-Haliczu (32,4 × 37,5 m) uznać należy za raczej skromne ${ }^{27}$.

${ }^{25}$ D. Dąbrowski, op. cit.

${ }^{26}$ T. Dzieńkowski, S. Gołub, W. Petryk, „Zespół rezydencjonalno-sakralny na Górze Katedralnej w Chełmie. Analiza stratygraficzna wykopów z badań archeologicznych w sezonach 2010-2012", Chełm 2013, mps w Archiwum IAE PAN w Warszawie.

27 Vide D. Chudzik, Chrześcijańska architektura sakralna Rusi Halickiej i Wołyńskiej (do końca panowania Daniela Romanowicza), Rzeszów 2014, s. 43. Prace są w toku, stąd podanie pełniejszych informacji na ten temat będzie możliwe po zakończeniu badań. 
W trakcie badań archeologicznych nie natrafiono na wymienioną w Kronice cerkiew św. Kosmy i Damiana. Była to budowla wzniesiona w technice monumentalnej (z kamienia? cegły?), co więcej, miała cztery ciosane kamienne kolumny (por. wyżej, tekst kroniki). Tymczasem miejsce jej lokalizacji pozostaje nieznane. W trakcie badań nie natrafiono też na elementy architektoniczne, które można by wiązać z tym obiektem.

\section{Słup czy wieża?}

Zagadkowa jest wzmianka kroniki o kolejnym monumencie, znajdującym się niedaleko chełmskiego grodu: „Stoi stołp popriszcze [w zależności od miary około 1,14-1,47 km] od grodu kamienny, a na nim orzeł kamienny rzeźbiony, wysokość kamienia dziesięć łokci z głowami/głowicą i z podnóżkami/podstawą, 12 łokci”. Ten fragment zapisu odnoszony jest najczęściej do reliktów innej kamiennej wieży znajdującej się na terenie obecnego miasta w dzielnicy Bieławin. Jeszcze w XIX w. zachowana była jego ściana na niemal całej wysokości (ryc. 8) ${ }^{28}$. Badania wykazały, że budowla ta mogła powstać w tym samym czasie co inne inwestycje doby danielowskiej, tj. w połowie wieku XIII ${ }^{29}$. Z możliwościami takiej identyfikacji formy polemizuje D. Dąbrowski, wskazując, że z tekstu kroniki wynika jednoznacznie, iż w tym przypadku mamy odniesienie do kamiennego słupa (kolumny?) z kamienną podstawą, zwieńczonego orłem ${ }^{30}$. Jeżeli tak było, mielibyśmy rzadki co do epoki i miejsca przykład monumentalnego pomnika z kolumną (?) sięgającego wieku XIII. Przyjmując taką interpretację, trudno z kolei wytłumaczyć obecność w tym miejscu, zachowanych nadal pozostałości kamiennej wieży.

\section{Struktura demograficzna i zajęcia mieszkańców Chełma czasów Daniela}

Interesującym wątkiem podnoszonym w kronice są odniesienia demograficzne i etnokulturowe dotyczące dawnych mieszkańców Chełma. Kwestiom tym poświęcono następujący ustęp: „Widział to książę Daniel, że Bóg pomaga miejscu temu, zaczął przyzywać, przychodźców - Niemcy i Ruś, innoplemieńcy i Lachowie szli dzień w dzień i młodzi [,] i majstrowie wszelacy uciekali od Tatarów, siodlarze i łucznicy [,] i tulnicy

${ }^{28}$ A. Lerue, Album Lubelskie rysowane z natury przez A. Lerue. Oddział II, z. 4: Chetm i wieża w Bieławinie - Wieża w Stołpiu - Zamek w Sielcu - Kościół w Spasie - Pomnik Chańskich w Uchaniach - Kościół w Tarnogórze, Warszawa 1860.

${ }_{29}$ Por. A. Buko, Średniowieczne kamienne wieże ziemi chełmskiej, „Przegląd Archeologiczny”, t. 62, 2014, s. 125-146; w cytowanej pracy starsza literatura.

30 D. Dąbrowski, op. cit. 
[wytwórcy kołczanów] [,] i kowale żelaza i miedzi [,] i srebra, i było życie [,] i napełnili dwory wokół grodu, pole i sioła".

Z zamieszczonego wyżej tekstu wynika, że Chełm w czasach Daniela był ośrodkiem polietnicznym, w którym znajdowali schronienie mieszkańcy różnych krajów, w tym wschodnich terenów, zagrożonych najazdami tatarskimi. Znaczącą grupę stanowić mieli wśród nich wykwalifikowani rzemieślnicy różnych specjalności. Opinię tę wspierają dotychczasowe wyniki badań archeologicznych. Mam na myśli zwłaszcza badania lat dziewięćdziesiątych XX w. przeprowadzone na terenach Zespołu Szkół Ogólnokształcących przy ul. Czarnieckiego. Zidentyfikowano tu ludną osadę wczesnomiejską z zabudową o charakterze rezydencjonalnym (drewniane dwory bojarów?) i licznymi warsztatami produkcyjnymi szklarskimi, ceramicznymi i świadectwami produkcji metalurgicznej. Na szczególną uwagę zasługuje odkrycie matryc do wyrobu srebrnych ozdób, tzw. kołtów, stanowiących element kultury elitarnej znanej ze środowiska bizantyjskiego, skąd wyroby te ekspandowały na inne terytoria, w tym do Rusi Kijowskiej ${ }^{31}$. Obecność w Chełmie matryc do ich produkcji świadczy o wysokiej randze ośrodka oraz o zapotrzebowaniu mieszkańców na wyroby luksusowe ${ }^{32}$.

O czym nie wzmiankuje Kronika halicko-wotyńska?

W tekście kroniki odnotowano brak odniesień do kilku ważnych zdarzeń, znajdujących poświadczenie w wynikach badań archeologicznych. Wielką enigmą pozostaje zwłaszcza kształt rezydencji książęcej. Z badań archeologicznych wynika, że w fazie najstarszej zespół rezydencjonalny składał się co najmniej z dwóch budowli - jednej o charakterze wieżowym (mieszkalnym?) i drugiej - przypuszczalnie sakralnej, usytuowanych w obrębie prostokątnego muru obwodowego, przeciętego w kolejnej fazie wieżą kamienną wkomponowaną w jego mur północny (por. ryc. 2). Jedynym punktem odniesienia w tej materii pozostaje wzmiankowana w kronice świątynia św. Jana, pełniąca najpewniej funkcję kaplicy pałacowej. $\mathrm{Na}$ obraz najstarszej rezydencji składałyby się zatem mury obwodowe z bramą oraz (na dziedzińcu) dwie budowle, z których jedna być może była wieżą mieszkalno-obronną, druga zaś - o planie zarysowującym

${ }^{31}$ S. Gołub, T. Dzieńkowski, Osada przygrodowa z czasów księcia Daniela Romanowicza $w$ Chetmie, w: Badania archeologiczne o poczatkach i historii Chetma, s. 57-71.

${ }^{32}$ Ibidem. 
niewymiarowy prostokąt - budowlą sakralną. Obie umieszczone były pośrodku dziedzińca na jednej osi.

W kronice nie znajdujemy też odniesień do katastrofy budowlanej, do jakiej najpewniej doszło $\mathrm{w}$ trakcie wznoszenia muru obwodowego rezydencji. Badania wykazały, że na całej powierzchni wewnątrz muru obwodowego, powyżej warstwy wyrównawczej pod posadzkę wybudowanej z zielonego glaukonitytu, zalega warstwa destruktów budowlanych o ponad metrowej miąższości (ryc. 9). Zarówno zatem w pierwszym jak i drugim wariancie interpretacyjnym przyjąć należałoby, że warstwa zielonego glaukonitytu wyznacza poziom budowlany nie tyle zakończony, ile przerwany. Wiele przesłanek wskazuje, że budowa rezydencji była już wtedy mocna zaawansowana. Świadczy o tym dowodnie wspomniana warstwa destruktów budowlanych udokumentowana zarówno wewnątrz murów obwodowych, jak i po stronie zewnętrznej muru północnego. Co więcej, można domniemywać, że budowa została przerwana w momencie wyposażania budowli w cenne elementy wystroju architektonicznego jej wnętrza bądź gromadzenia ich na placu budowy. Część z nich znajdowana była bowiem wśród wspomnianych destruktów. Brak zachowanego muru obwodowego wschodniego, ale zarazem obecność jego szczątków na znacznej głębokości wskazują, że runął on ze skarpy wschodniej, zanim został w pełni wybudowany. W wyniku zaistniałych wydarzeń i wobec ogromu nagromadzonych materiałów budowlanych zdecydowano najpewniej kontynuować budowę rezydencji, ale w zmienionej formie.

Opisywany epizod został przemilczany przez kronikę. Tymczasem obserwujemy różnice warsztatowe i surowcowe pomiędzy murem obwodowym i częścią bramą - z jednej strony, a pozostałymi budowlami, jakie powstawały na tym terenie. Jest to wyraźne zderzenie tradycji budownictwa rzymskiego (opus quadratum) z techniką warstwowanego łamanego kamienia łączonego zaprawą, charakterystyczną dla budownictwa średniowiecznego „barbarzyńskiej” części Europy. Odnotowano, że wszystkie budowle powstałe w fazie drugiej (ok. 1240 r.?), poza wtórnie wykorzystanym murem obwodowym, reprezentują "zbarbaryzowane" surowce i techniki budowlane. Nie wiemy jednak, czy pierwotny plan rezydencji w wyniku katastrofy budowlanej został zmieniony, co skutkowało zmianą warsztatu budowlanego, materiałów skalnych i szerzej koncepcji całości.

Zastanawia też milczenie kroniki na temat trzeciej wieży wzniesionej w pobliskim Stołpiu. Jest to o tyle dziwne, że zgodnie z wynikami przeprowadzonych badań mógł to być pierwszy monumentalny obiekt wzniesiony na ziemi chełmskiej jeszcze w czasach Romana Halickiego, 
przebudowany w czasach danielowskich ${ }^{33}$. W kolejnej fazie rozbudowy umieszczono w niej oktagonalną kaplicę, zlokalizowaną na ostatniej kondygnacji. Zastanawia, dlaczego tak charakterystyczny i unikatowy obiekt obronno-sakralny, znajdujący się na przedpolu książęcego zespołu rezydencjonalnego, nietypowy w tej części Europy, znalazł się na poboczu zainteresowań kronikarskich.

Tekst Kroniki halicko-wołyńskiej umożliwia konfrontację zapisu kronikarskiego z odkryciami archeologicznymi. W wielu przypadkach zgodność tekstu z wynikami badań nie budzi wątpliwości. Ale w odniesieniu do rezydencji książęcej autor kroniki podaje najczęściej kilka wybranych, interesujących go szczegółów, brak natomiast danych na temat jej cech przestrzennych. W kilku przypadkach stwierdzono odmienne (lub niejednoznaczne) formy obiektów zidentyfikowanych w terenie, w stosunku do zapisu kronikarskiego (np. Bieławin). Niekiedy (np. wymieniona w kronice studnia) lokalizacja zidentyfikowanych podczas badań obiektów nie odpowiada ich położeniu zgodnie z zapisem kronikarskim. Kilku ważnych obiektów kronika w ogóle nie wymienia (np. Stołpie), podczas gdy inne, dotąd nie odkryte, w kronice znajdują odniesienia imienne (np. świątynie św. Trójcy czy św. św. Kosmy i Damiana). Przesadzone wydają się określenia dotyczące wielkości niektórych świątyń (np. najstarsza bazylika chełmska). Odnotowano też brak w zapisach kronikarskich wzmianek o katastrofie budowlanej zaistniałej na etapie budowy rezydencji, zidentyfikowanej w trakcie badań archeologicznych. Niektóre obiekty architektoniczne pojawiają się w tekście kroniki, jeżeli mają określone znaczenie kontekstualne, np. świątynia św. Trójcy - tu ze względu na jej pożar i późniejszą odbudowę. Z przedmiotowego tekstu kroniki zdaje się też wynikać, że nazwą „gród” określano nie tylko fortyfikacje drewniano-ziemne, ale również zespół kamiennych budowli o charakterze rezydencjonalnym i obronnym. Autor kroniki używa też jednego terminu (budowla kamienna) dla określenia obiektów wykonanych zarówno z kamienia, jak i cegły.

Ogólna forma rezydencji książęcej wymaga dalszych badań i uściśleń. Wynika to z faktu, że jej forma wykracza daleko poza standardy miejsca i epoki. T. Rodzińska-Chorąży uważa jej projekt wręcz za awangardowy, zaznaczając, że ani na Rusi Kijowskiej, ani Rusi Halicko-Wołyńskiej tego czasu, ani też na terenach piastowskich, czy w Czechach - nie były znane

33 Por. odpowiednie rozdziały w pracy: Zespół wieżowy w Stołpiu. Badania 2003-2005, red. A. Buko, Warszawa 2009. 
podobne rozwiązania. Chodzi tu o wieloelementowe murowane budowle rezydencjonalne i budynki im towarzyszące (świeckie i sakralne) objęte zwartym systemem fortyfikacji. Tego typu obiekty pojawiają się na ziemiach polskich dopiero po połowie XIII w. za sprawą Krzyżaków i ich sieci zamków konwentualnych i biskupich. Zdaniem T. Rodzińskiej-Chorąży materiałem porównawczym na dzisiaj zdaje się siedziba królewska w Obudzie na Węgrzech ${ }^{34}$. Pośrednio na rzecz niestandardowych rozwiązań chełmskiej rezydencji przemawiają dane wynikające $\mathrm{z}$ analizy cech materiałów i surowców użytych do wzniesienia odkrywanych budowli. Lucjan Gazda zwraca uwage, że realizacja zespołu rezydencjalno-sakralnego na Górze Katedralnej w Chełmie angażowała unikatowe, często importowane surowce i materiały, ale także była miejscem eksperymentów technologicznych, nadającym tutejszej architekturze nowe, wyrafinowane standardy. Zdaniem tego autora materiały wykorzystywane przy budowie rezydencji chełmskiej traktować należy jako efekt nie tylko transpozycji, ale również udoskonaleń osiągnięć dwunasto- i trzynastowiecznej szkoły halickiej, spajającej najwyższe techniki i technologie bizantyjskiego Wschodu i romańskiego Zachodu ${ }^{35}$.

Zapewne wiele spośród sygnalizowanych wyżej niewiadomych można będzie uściślić poprzez poszerzenie zakresu badań. Obecnie nie bardzo bowiem wiadomo, jak była zagospodarowana północna część Wysokiej Górki oraz czy znajdująca się w południowej części Góry Katedralnej bazylika, zatem poza ścisłym obszarem Wysokiej Górki, była w grodzie, czy też w dzielnicy miejskiej. Rozwiązanie tych, podobnie jak i wielu innych problemów - to istotne zadanie dla ekipy badawczej na najbliższą przyszłośćc ${ }^{36}$.

34 T. Rodzińska-Chorąży, op. cit.

35 L. Gazda, „Surowce, materiały i technologie XIII-wiecznego zespołu rezydencjonalno-sakralnego na Górze Katedralnej w Chełmie", Lublin 2012, mps w Archiwum IAE PAN w Warszawie.

${ }^{36}$ W latach 2015-2017 północna część Wysokiej Górki będzie przedmiotem archeologicznych badań interdyscyplinarnych realizowanych pod kierunkiem autora niniejszego artykułu, w ramach nowego projektu Narodowego Centrum Nauki przyznanego Instytutowi Archeologii i Etnologii PAN. Wstępne prace terenowe przeprowadzone latem 2015 r. wskazują, że również ta część wyniesienia objęta została w średniowieczu zabudową monumentalną. 


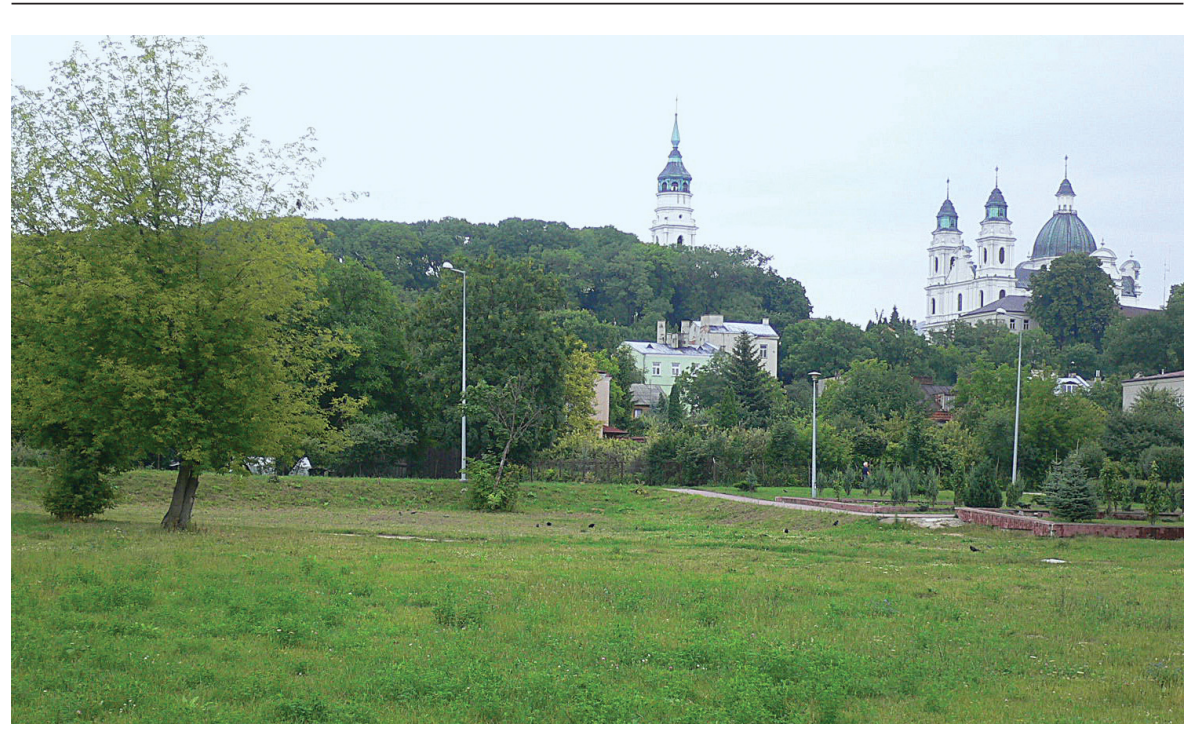

Ryc. 1. Góra Katedralna w Chełmie. Po lewej stronie widoczne wyniesienie Wysokiej Górki, na prawo - dzwonnica i bazylika katedralna Narodzenia NMP. Widok od zachodu. Fot. A. Buko.

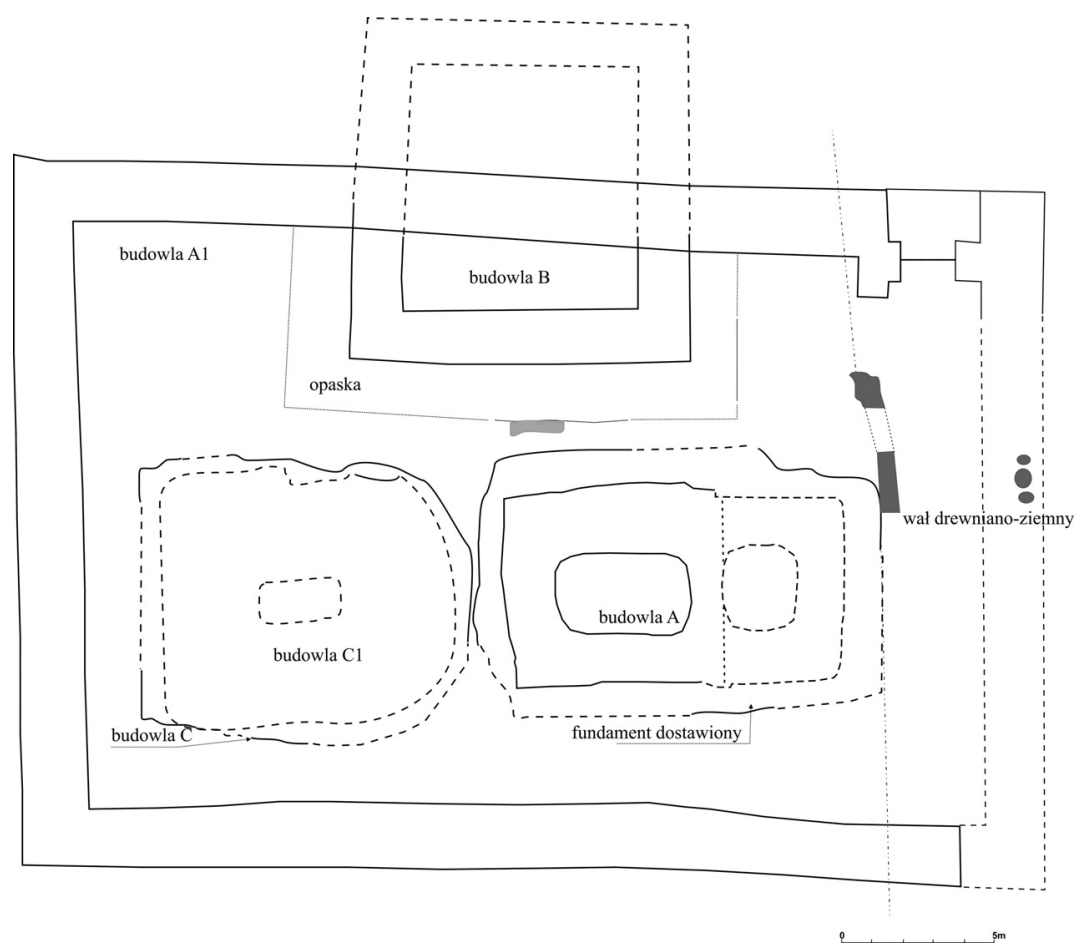

Ryc. 2. Plan odkryć architektonicznych na Wysokiej Górce (północna część Góry Katedralnej w Chełmie) (wg T. Dzieńkowskiego). 


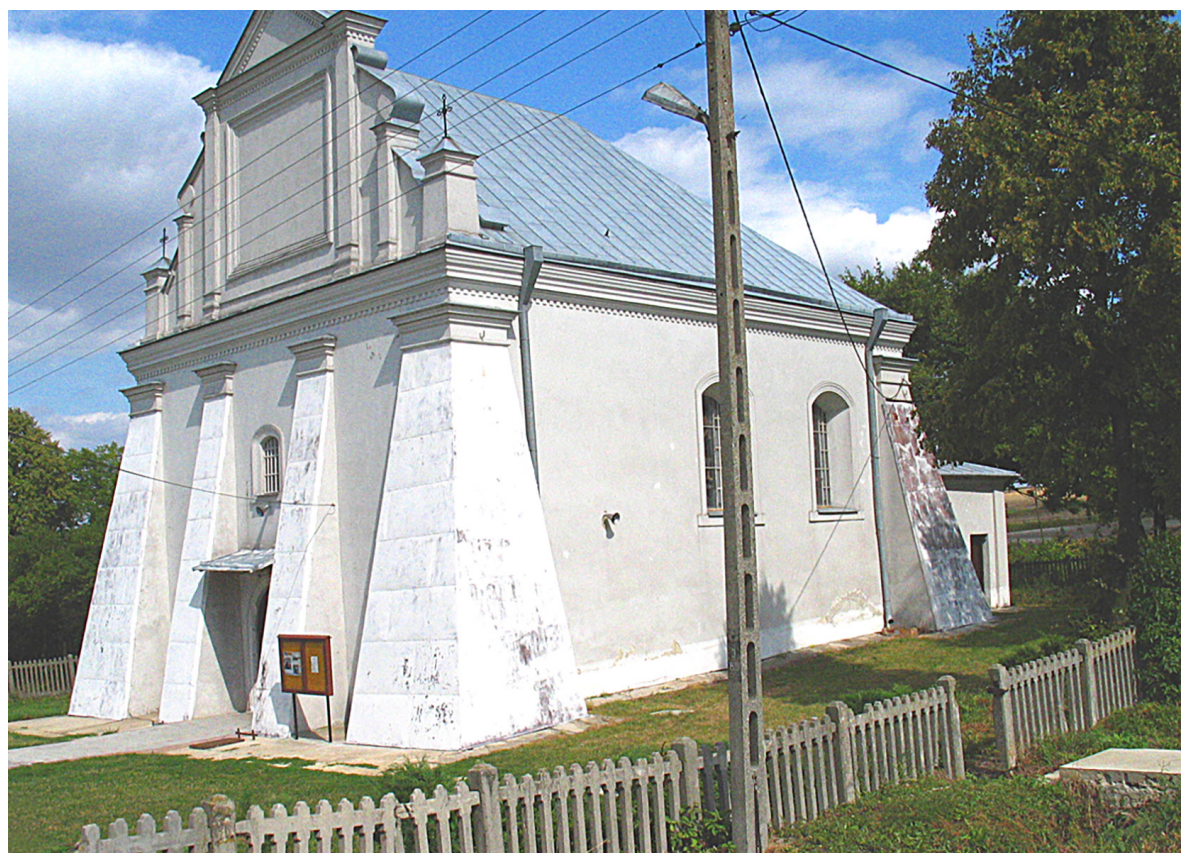

Ryc. 3. Kościół parafialny w Spasie-Podgórzu k. Chełma. W jego części prezbiterialnej i części nawy głównej zidentyfikowano budowlę sakralną datowaną na wiek XIII. Widok od płd.-zach. Fot. A. Buko.

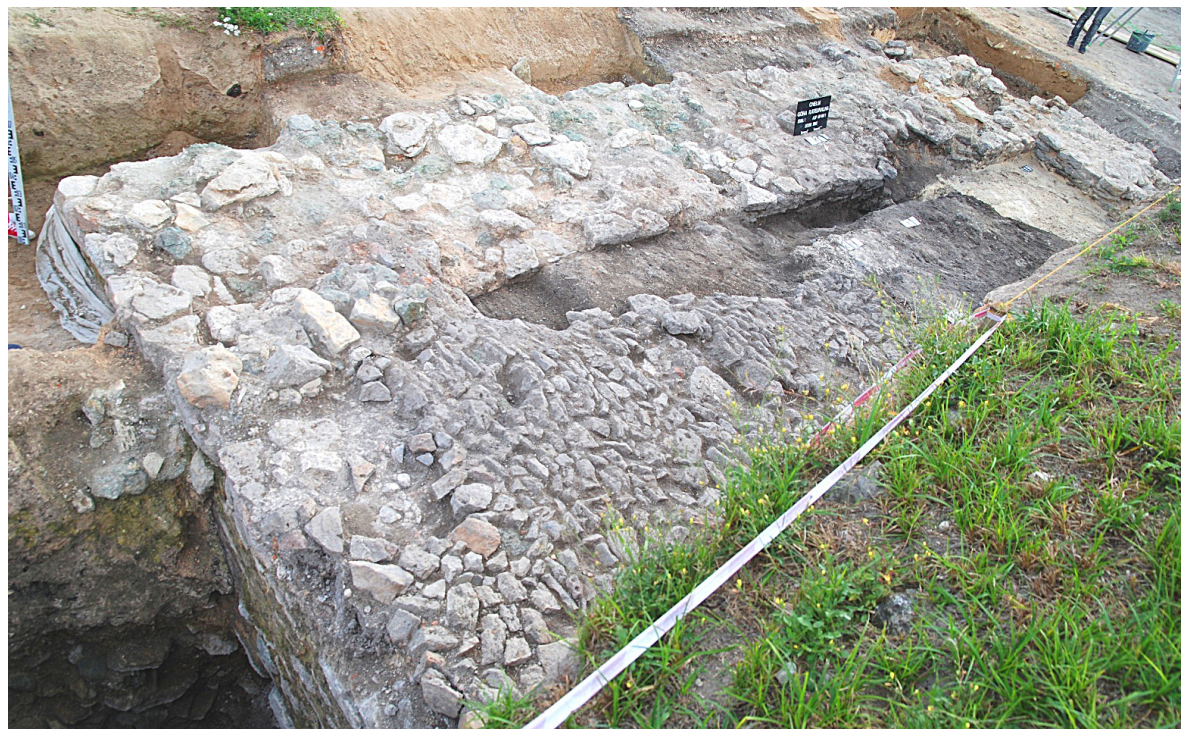

Ryc. 4. Relikty wieży kamiennej (tzw. budowla B), wkomponowanej w mur północny muru obwodowego rezydencji książęcej (por. ryc. 2). Obiekt w większej części zalega pod nowożytnym Kopcem Niepodległości. Widok z góry, od płn.-wsch. Fot. A. Buko. 


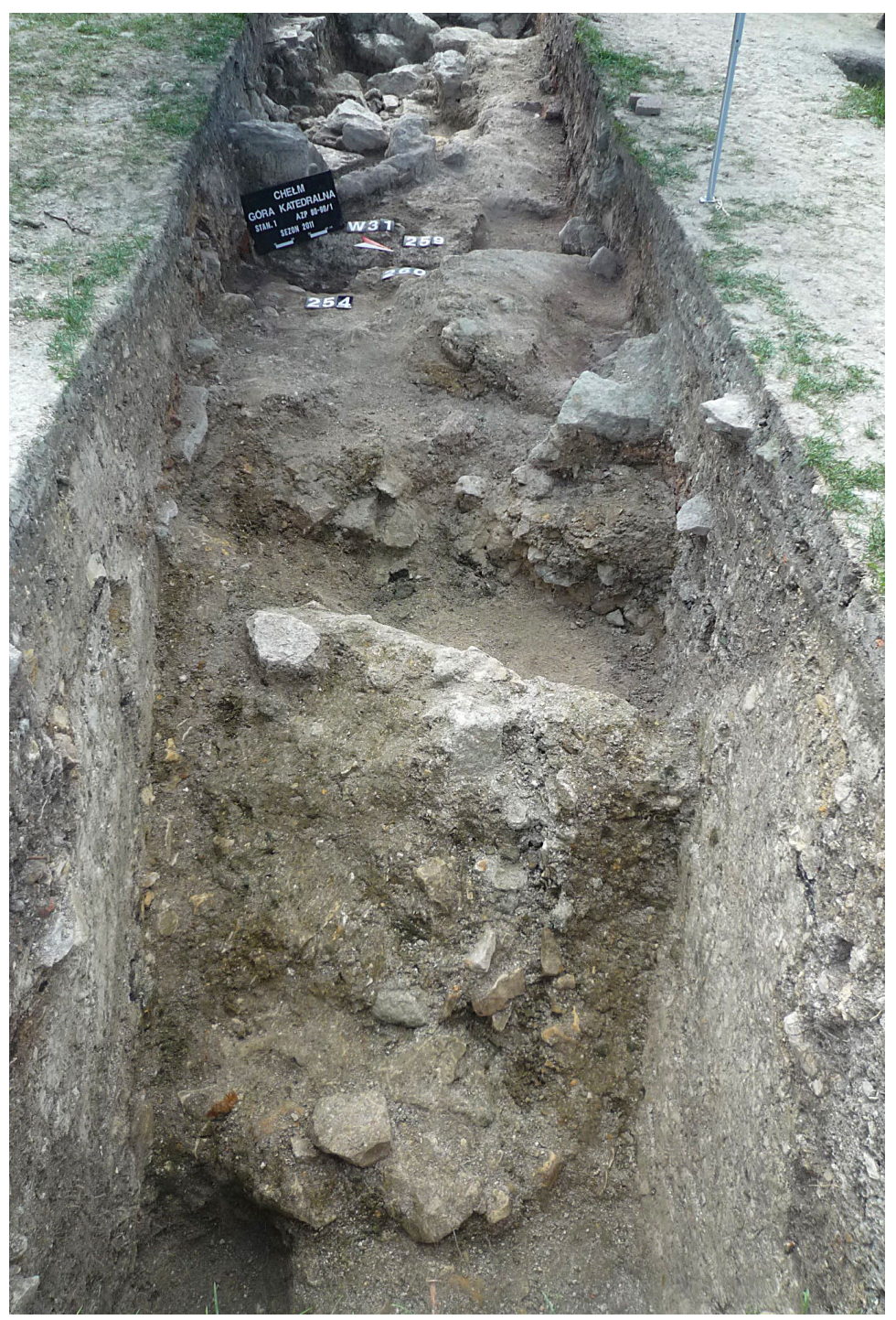

Ryc. 5. Warstwy spalonych destruktów odsłonięte w wykopie nr 31 - archeologiczne świadectwa wielkiego pożaru z 1256 r. (?). Fot. A. Buko. 


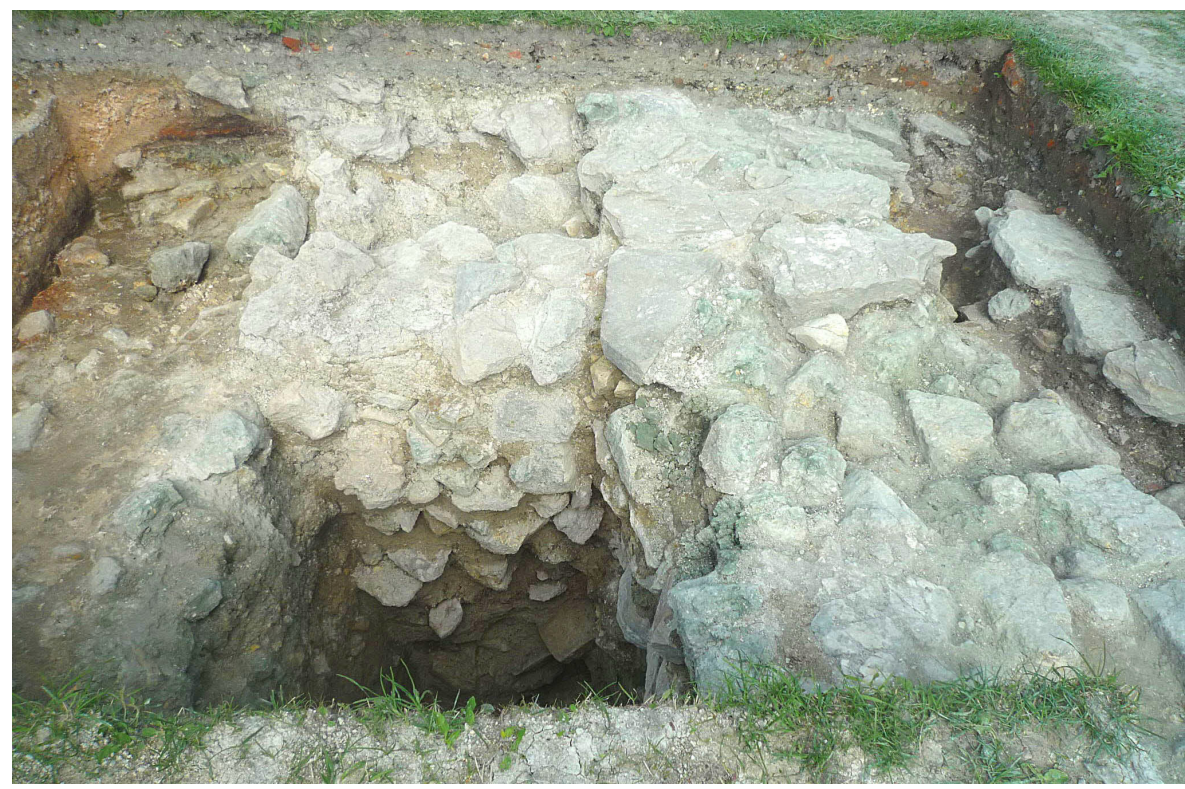

Ryc. 6. Podwójny mur - poszerzona ściana budowli sakralnej (?), tzw. budowla A: archeologiczne świadectwa naprawy po pożarze (?) z 1256 r. Fot. A. Buko.

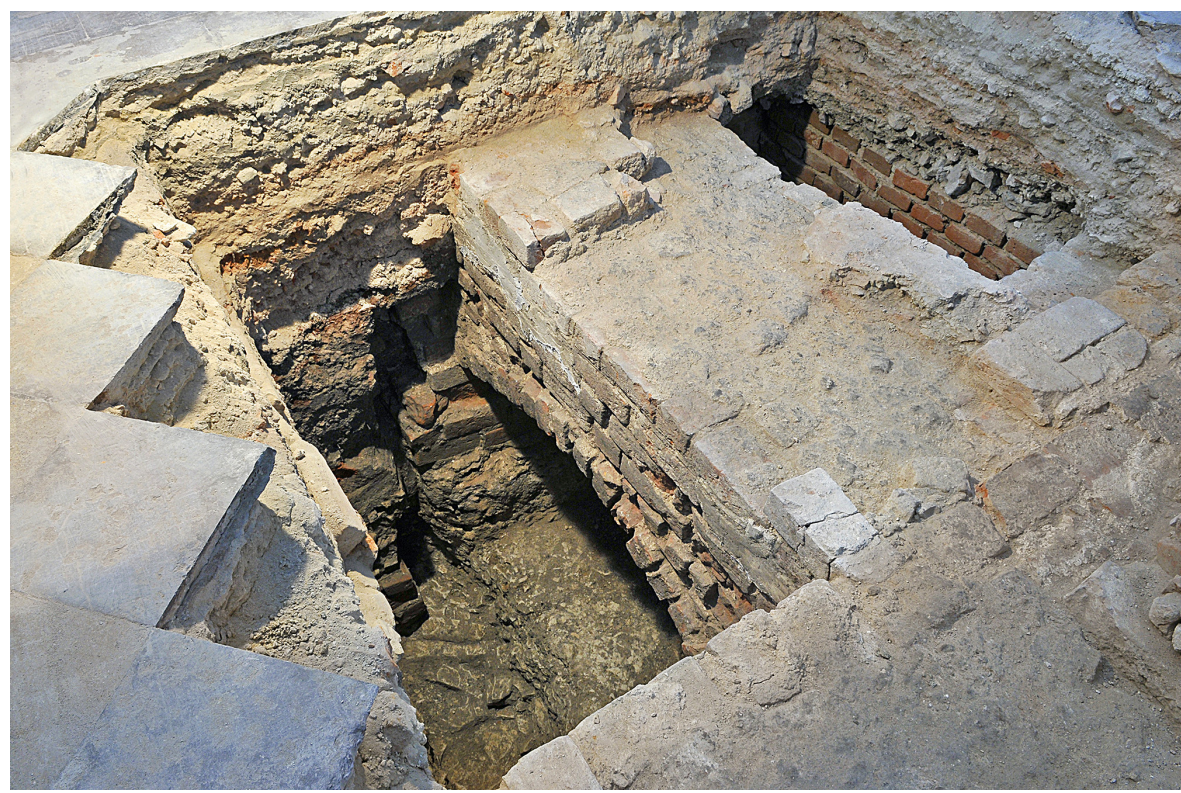

Ryc. 7. Fragment ceglanego muru ściany zachodniej świątyni z XIII w. (fundacja Daniela Romanowicza) odsłoniętego w 2013 r. pod posadzką obecnej bazyliki katedralnej. W murze widoczne sklepienie krypty grobowej. Fot. S. Gołub. 


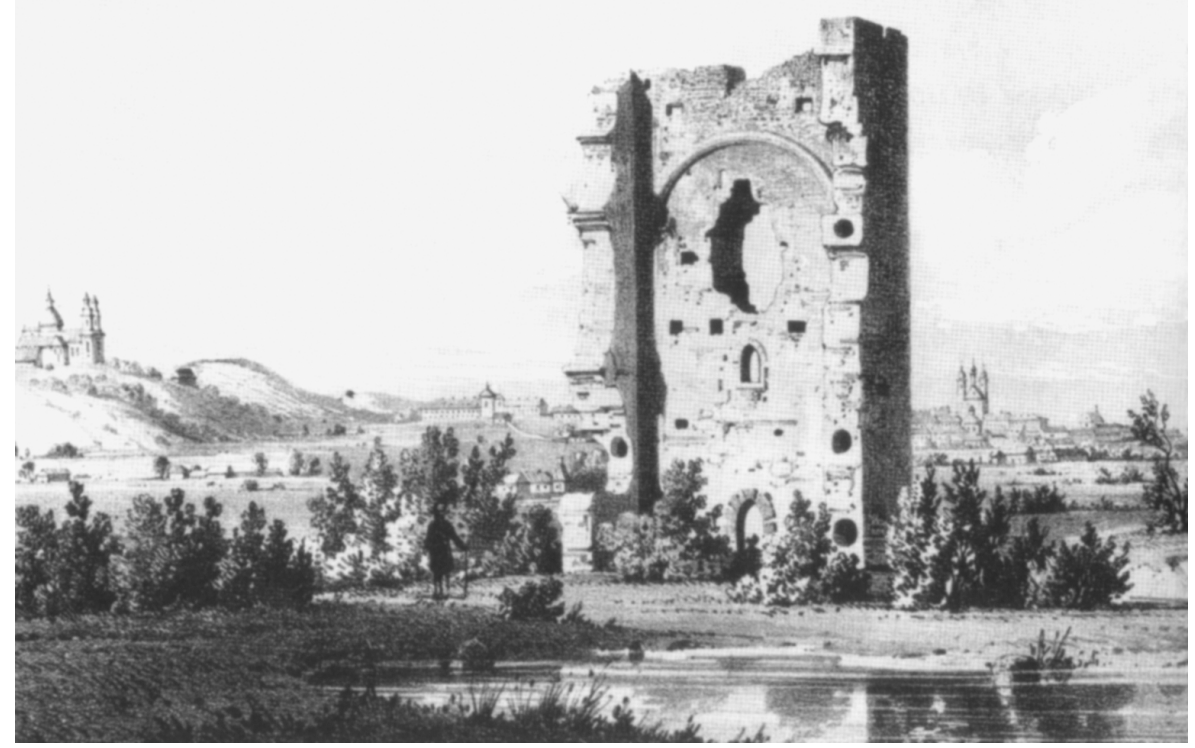

Ryc. 8. Widok reliktów kamiennej wieży w Chełmie-Bieławinie w drugiej połowie XIX w. (wg A. Lerue).

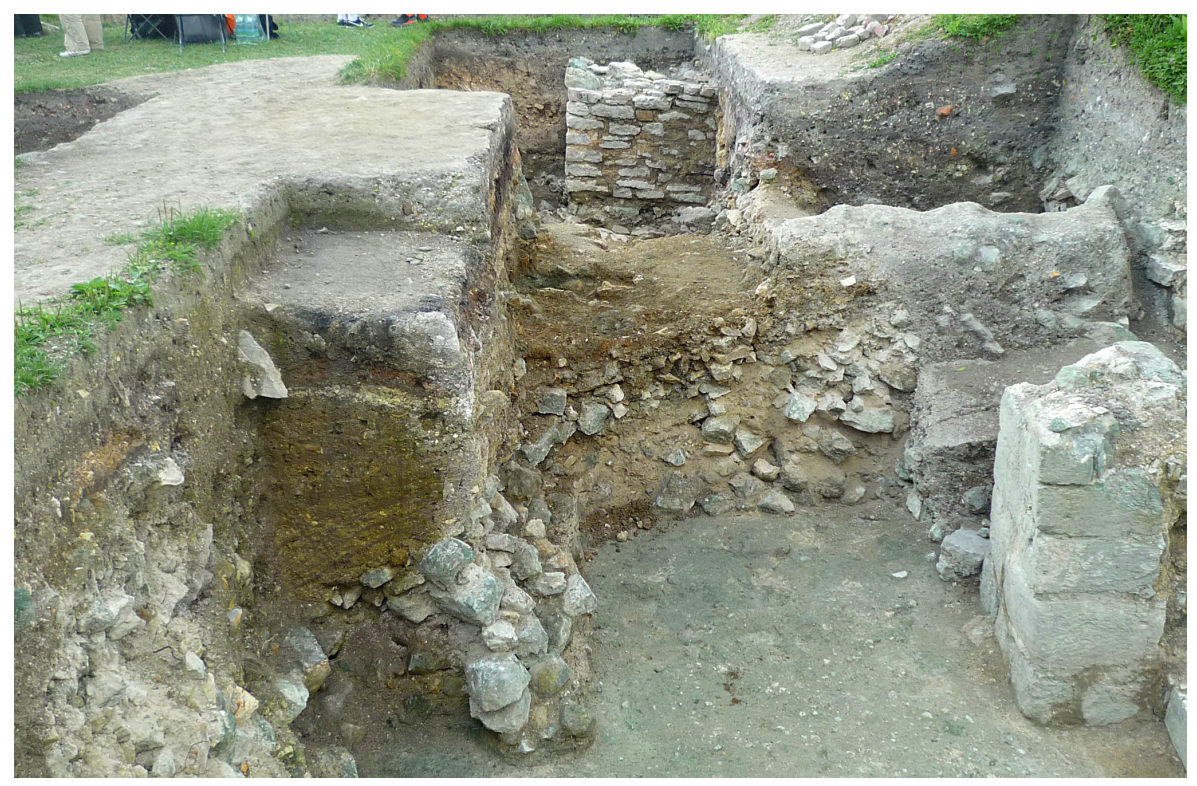

Ryc. 9. Odsłonięte elementy rezydencji Danielowskiej fazy I oglądane od części bramnej (po prawej stronie). Powyżej poziomu posadzki (na pierwszym planie) zalega gruba warstwa materiałów budowlanych, na której budowano obiekty kolejnej fazy, w tym kamienną wieżę (budowla B) - widoczna u góry. Widok od wsch. Fot. A. Buko. 


\section{Streszczenie}

Archeolodzy badający zabudowę rezydencjonalną Daniela Romanowicza na Górze Katedralnej w Chełmie (XIII w.) mają godną uwagi płaszczyznę porównań dokonywanych odkryć z tekstem Kroniki halicko-wołyńskiej. Jest wysoce prawdopodobne, że przynajmniej niektóre spośród zamieszczonych w Kronice opisów miejsc i obiektów pochodzić mogą z pierwszej ręki. Dla badacza, nie będącego specjalistą w zakresie krytycznej analizy tekstów źródłowych, konfrontacja zapisów kronikarskich z odkryciami archeologicznymi jest więc interesującym wyzwaniem. W artykule przedstawiono dylematy archeologa, który mając do dyspozycji różne kategorie danych, próbuje je porównywać z zapisami kronikarskimi.

Tekst kroniki dostarcza interesujących danych na temat położenia miasta Chełma, elementów zabudowy Góry Katedralnej, w tym lokalizowanego tam ośrodka grodowego, niektórych świątyń i świeckich elementów zabudowy monumentalnej, pożaru miasta odnotowanego w kronice pod rokiem 1256, jak również zagadkowego wieżowego obiektu położonego w okolicach miasta, a także struktury demograficznej i etnokulturowej oraz zajęć mieszkańców miasta czasów Daniela i innych.

Odnotowano, że w kronice brak jest odniesień do kilku istotnych elementów, znajdujących poświadczenie w wynikach badań archeologicznych. Wielką enigmą pozostaje kształt rezydencji książęcej. W kronice nie znajdujemy też odniesień do katastrofy budowlanej, jaka najpewniej wydarzyła się w trakcie wznoszenia muru obwodowego rezydencji. Zastanawia też milczenie źródła na temat trzeciej wieży wzniesionej w pobliskim Stołpiu. Jest to o tyle dziwne, że zgodnie z wynikami przeprowadzonych badań mógł to być pierwszy monumentalny obiekt wzniesiony na ziemi chełmskiej jeszcze w czasach Romana Romanowicza, przebudowany w czasach danielowskich. Pozostaje zatem zagadką, dlaczego tak charakterystyczny i unikatowy obiekt obronno-sakralny, znajdujący się na przedpolu książęcego zespołu rezydencjonalnego, nietypowy w tej części Europy, znalazł się na poboczu zainteresowań kronikarskich.

W innych przypadkach tekst Kroniki halicko-wołyńskiej umożliwia konfrontację zapisu kronikarskiego z odkryciami archeologicznymi. Niejednokrotnie zgodność tekstu z wynikami badań nie budzi wątpliwości. Ale w odniesieniu do rezydencji książęcej autor kroniki podaje najczęściej kilka wybranych, interesujących go szczegółów, brak natomiast danych na temat jej formy i cech przestrzennych.

Zapewne wiele spośród sygnalizowanych wyżej niewiadomych można będzie uściślić poprzez poszerzenie zakresu badań. Nie bardzo nadal bowiem wiadomo, jak była zagospodarowana północna część Góry Katedralnej oraz czy znajdująca się w południowej jej części bazylika była w grodzie, czy też w dzielnicy miejskiej. Rozwiązanie tych, podobnie jak i wielu innych problemów stanowi istotne zadanie dla ekipy badawczej na najbliższą przyszłość. 


\section{Written Sources and Archaeology: the Example of Cathedral Hill in Chełm}

Archaeologists examining the residence of Daniel Romanovych on Cathedral Hill in Chełm (thirteenth century) enjoy a noteworthy opportunity to compare excavations with the text of Kronika halicko-wotynska (The Galician-Volhynian Chronicle). It is highly probable that at least some of the descriptions of places and objects in the Chronicle could have been first-hand. For a researcher who does not specialise in a critical analysis of text sources such a confrontation of chronicle records with archaeological discoveries becomes, therefore, an exciting challenge. The article discusses the dilemmas of an archaeologist who, with assorted categories of data at his disposal, tries to confront them with a chronicler's account.

The text of the chronicle provides interesting information concerning the location of the town of Chełm, elements of the development of Cathedral Hill, including the town-castle centre situated here, some churches and secular elements of monumental architecture, the town fire recorded in the chronicle in 1256, as well as a mysterious tower standing in the urban area, the town's demographic and ethno-cultural structure, and the occupation of its residents at the time of Daniel.

It has been noted that the chronicle lacks references to several essential elements confirmed in the outcome of archaeological studies. The shape of the ducal residence remains an important unsolved enigma. The chronicle also does not discuss the construction catastrophe that probably took place in the course of building the circumferential wall of the residence. Another noteworthy feature is the written source's silence concerning the third tower (bergfried) erected in nearby Stołpie. This omission is particularly strange considering that in accordance with the results of the conducted research the tower could have been the first monumental building raised in the land of Chełm already during the period of Roman Romanovych and redesigned at the time of Daniel. It thus remains a mystery why such a characteristic and unique defensive-sacral edifice, located in the fore-field of the ducal residential complex and highly untypical for this part of Europe, was relegated to the sidelines of the chronicler's interest.

In other instances, the text of Kronika halicko-wotyńska makes it possible to confront the written record with archaeological findings. Upon numerous occasions the concurrence of the written accounts with the outcome of the excavations does not give rise to doubt. Nonetheless, in reference to the ducal residence the author of the chronicle mentioned a number of selected details of interest to him, but neglected to include data about its forms and spatial features.

It is highly likely that many of the above-listed unidentified facts could be determined by expanding the range of studies. We still do not have information about the northern part of Cathedral Hill or whether the basilica located in the southern part stood within the stronghold or the town district. The solution of those issues, and many similar problems, remains an essential task for the next future. 


\section{Bibliografia}

Baran, Oleksandr. „Datuvannâ zasnuvannâ mìsta Holma v Galic'ko-Volins'komu lìtopisì". Ukraïna v Central'no-Shìdnì Êvropì (z najdavniših časiv do kìncâ XVIII st.) 5 (2005): 428-448.

Baran, Oleksandr. „Rann'omoderna knižna tradiciâ pro Holm XI stolìttâ”. Ruthenica 4 (2005): 98-114.

Buko, Andrzej. Archeologia Polski wczesnośredniowiecznej. Odkrycia - hipotezy - interpretacje. Wyd. 3. Warszawa: Wydawnictwo Trio, 2011.

Buko, Andrzej. „Monumentalna zabudowa Góry Katedralnej w Chełmie”. Archaeologia Historica Polona 15, nr 1 (2005): 69-83.

Buko, Andrzej. „Średniowieczne kamienne wieże ziemi chełmskiej”. Przegląd Archeologiczny 62 (2014): 125-146.

Buko, Andrzej, red. Zespót wieżowy w Stotpiu. Badania 2003-2005. Warszawa: Instytut Archeologii i Etnologii PAN, 2009.

Buko, Andrzej, Radosław Dobrowolski, Tomasz Dzieńkowski, Stanisław Gołub, Wasyl Petryk, Teresa Rodzińska-Chorąży. „A palatium or residential complex? Recent research into the northern part of Góra Katedralna (Wysoka Górka). Chełm / Palatium czy zespół rezydencjonalny? Północna część Góry Katedralnej w Chełmie (Wysoka Górka) w świetle wyników najnowszych badań". Sprawozdania Archeologiczne 66 (2014): 101-154.

Chudzik, Dominik. Chrześcijańska architektura sakralna Rusi Halickiej i Wołyńskiej (do końca panowania Daniela Romanowicza). Rzeszów: Instytut Archeologii Uniwersytetu Rzeszowskiego; Fundacja Rzeszowskiego Ośrodka Archeologicznego, 2014.

Dąbrowski, Dariusz. „Źródła pisane do dziejów Góry Katedralnej w Chełmie”. W „Zespół rezydencjonalno-sakralny na Górze Katedralnej w Chełmie”. Wyniki badań, Instytut Archeologii i Etnologii PAN w Warszawie, 2013.

Dzieńkowski, Tomasz. „Góra Chełmska we wczesnym średniowieczu”. W Badania archeologiczne o poczatkach i historii Chetma, red. Ewa Banasiewicz-Szykuła, 73-83. Lublin: Wojewódzki Oddział Służby Ochrony Zabytków, 2002.

Dzieńkowski, Tomasz. „Das mittelalterliche Chełm im Lichte archaologischer Quellen / Średniowieczny ośrodek chełmski w świetle źródeł archeologicznych". Analecta Archaeologica Ressoviensia 7 (2012): 371-458.

Dzieńkowski, Tomasz. „Wczesnośredniowieczne osadnictwo ziemi chełmskiej”. Praca doktorska, Instytut Archeologii i Etnologii PAN w Warszawie, 2010.

Dzieńkowski, Tomasz, Stanisław Gołub, Wasyl Petryk. „Zespół rezydencjonalno-sakralny na Górze Katedralnej w Chełmie. Analiza stratygraficzna wykopów z badań archeologicznych w sezonach 2010-2012”. Wyniki badań, Instytut Archeologii i Etnologii PAN w Warszawie, 2013.

Gazda, Lucjan. „Surowce, materiały i technologie XIII-wiecznego zespołu rezydencjonalno-sakralnego na Górze Katedralnej w Chełmie". Wyniki badań, Instytut Archelogii i Etnologii PAN w Warszawie, 2012.

Gołub, Stanisław. „Badania archeologiczne chełmskich studni zabytkowych”. Rocznik Chetmski 3 (1997): 369-381.

Gołub, Stanisław, Tomasz Dzieńkowski. „Osada przygrodowa z czasów księcia Daniela Romanowicza w Chełmie". W Badania archeologiczne o początkach i historii 
Chełma, red. Ewa Banasiewicz-Szykuła, 57-71. Lublin: Wojewódzki Oddział Służby Ochrony Zabytków, 2002.

Jusupović, Adrian. „«Богу же изволившю Данилъ созда градъ Холмъ». Geneza Chełma i jego biskupstwa”. Rocznik Instytutu Europy Środkowo-Wschodniej 12, z. 6 (2014): 11-26.

Kłoczowski, Jerzy. „Zarys historii rozwoju przestrzennego miasta Chełma”. Roczniki Humanistyczne 6, nr 5 (1958): 193-221.

Lerue, Adam. Album Lubelskie rysowane z natury przez A. Lerue. Oddział II. Z. 4, Chetm $i$ wieża w Bieławinie - Wieża w Stołpiu - Zamek w Sielcu - Kościół w Spasie Pomnik Chańskich w Uchaniach - Kościół w Tarnogórze. Warszawa: Drukarnia Jana Jaworskiego, 1860.

Natkański, Karol. „Początki kultu na Górce Chełmskiej”. Eastern Review 4 (2000): 411-423.

Natkański, Karol. „Studnia na Górce Katedralnej w Chełmie”. Rocznik Chełmski 3 (1997): 383-391.

Poppe, Andrzej. „Gród Wołyń. Z zagadnień osadnictwa wczesnośredniowiecznego na pograniczu polsko-ruskim”. Studia Wczesnośredniowieczne 4 (1958): 227-300. Rappoport, Pavel Aleksandrovič. „Cholm”. Sovetskaâ arheologiâ 20 (1954): 313-323. Rodzińska-Chorąży, Teresa. „Relikty architektoniczne zespołu rezydencjonalnego na Wysokiej Górce w Chełmie”. W „Zespół rezydencjonalno-sakralny na Górze Katedralnej w Chełmie". Wyniki badań, Instytut Archeologii i Etnologii PAN w Warszawie, 2013.

Rudnik, Stanisława. „Wyniki badań architektonicznych kościoła w Podgórzu, gm. Chełm". W Najważniejsze odkrycia archeologiczno-architektoniczne Chełma i okolic. Materiaty z sesji naukowej odbytej w Chełmie 1 XII 1995 r., red. Stanisław Gołub, 39-52. Chełm: Towarzystwo Opieki nad Zabytkami Oddział Wojewódzki w Chełmie, 1997.

Ruszkowska, Urszula. „Chełm-Bieławin. U źródeł miasta”. W Badania archeologiczne o początkach i historii Chełma, red. Ewa Banasiewicz-Szykuła, 37-56. Lublin: Wojewódzki Oddział Służby Ochrony Zabytków, 2002.

Ruszkowska, Urszula. „Czy na Górce Chełmskiej znajdowało się miejsce kultu pogańskiego?”. Eastern Review 4 (2000): 405-410.

Ruszkowska, Urszula. „Ze studiów nad wczesnośredniowiecznym rejonem osadniczym w Chełmie-Bieławinie". Lubelskie Materiały Archeologiczne 3 (1990): 55-89.

Smorąg-Różycka, Małgorzata. „L'Architecture sacrale orthodoxe de Galicie-Volhynie du XIIIe siècle: une synthèse des formes traditionnelles Byzantines et romanes?". Byzantina et Slavica Cracoviensis 3 (2001): 181-192.

Zimmer, Bolesław. Miasto Chetm. Zarys historyczny. Warszawa: PWN, 1974.

Biogram: Prof. dr hab. Andrzej Buko - profesor w Instytucie Archeologii i Etnologii PAN, profesor zwyczajny Uniwersytetu Warszawskiego. Głównym obszarem jego zainteresowań są pogranicza etniczne i kulturowe w kontekście formowania się państwa polskiego (e-mail: abuko@uw.edu.pl). 